\title{
Provincial logistics costs in South Africa's Western Cape province: Microcosm of national freight logistics challenges
}

\author{
Authors: \\ Jan H. Havenga ${ }^{1}$ \\ Leila L. Goedhals-Gerber ${ }^{1}$ \\ Anneke de Bod ${ }^{1}$ \\ Zane Simpson ${ }^{1}$ \\ Affiliations: \\ ${ }^{1}$ Department of Logistics, \\ Stellenbosch University, \\ South Africa \\ Correspondence to: \\ Jan Havenga \\ Email: \\ janh@sun.ac.za \\ Postal address: \\ Private Bag X1, Matieland \\ 7602 , South Africa \\ Dates: \\ Received: 29 July 2015 \\ Accepted: 13 Aug. 2015 \\ Published: 30 Sept. 2015 \\ How to cite this article: \\ Havenga, J.H., Goedhals- \\ Gerber, L.L., De Bod, A. \\ \& Simpson, Z., 2015, \\ 'Provincial logistics costs \\ in South Africa's Western \\ Cape province: Microcosm \\ of national freight logistics \\ challenges', Journal of \\ Transport and Supply Chain \\ Management 9(1), Art. \#206, \\ 8 pages. http://dx.doi. \\ org/10.4102/jtscm.v9i1.206

\section{Copyright:} \\ C 2015. The Authors. \\ Licensee: AOSIS \\ OpenJournals. This work is \\ licensed under the Creative \\ Commons Attribution \\ License.
}

\section{Read online:}

Background: Logistics costs are most commonly measured on a national level. An understanding of the provincial logistics landscape can add significant value both to provincial and national policy interventions; such measurements are however scarce. South Africa's national freight logistics survey points to significant challenges in the structure of the freight transport market, most importantly the dominance of road freight transport on dense, longdistance corridors. The Cape Town-Gauteng corridor is the main economic artery linking the Western Cape province to the rest of the country.

Objectives: The provincial government commissioned this research to develop an understanding of the province's contribution to the national logistics challenges in order to alleviate both provincial and national logistics challenges.

Results: The research results provide a distinct description of the key action required - to provide an intermodal solution for the dense flows of fast-moving consumer goods on the Cape Town-Gauteng corridor in order to reduce the significant transport and externality costs related to these flows and reduce exposure to exogenous cost drivers.

Conclusion: Collaborative research between government and private industry into appropriate intermodal technologies must be prioritised within the ambit of South Africa's socioeconomic environment. This shift can be further supported through the internalisation of road transport externalities to enable a total cost decision between modes, as well as through appropriate regulation of the freight transport industry.

\section{Introduction}

Logistics cost measurement most commonly takes place on a national level as an indicator for evaluating and monitoring logistics performance to inter alia guide logistics and related policymaking and infrastructure investment decisions (Rantasila 2010). The measurement of logistics costs on a provincial or regional level within a country is more uncommon, the major limitation being the lack of sufficiently disaggregated data sources and funding to develop such (Davydenko \& Tavasszy 2013). Two distinct paradigm shifts however confirm the necessity of a better regional understanding of both freight flows and logistics costs. The first is the growing acknowledgement that economic re-localisation is one of the anchors of sustainable economies (North 2010); the second is that of recognising logistics as an indispensable value creator on a macroeconomic and microeconomic scale (Rossouw, as cited in Tsedu 2012).

The value creation role is especially pertinent in South Africa, where the most recent national state of logistics survey reiterated the disproportionate contribution of transport costs at $61 \%$ of logistics costs in 2012, compared to 39\% globally (Roberts 2003; Rodrigue, Comtois \& Slack 2009). This is a result of the country's excessive dependence on road transport with a road long-distance tonne-kilometre market share of $85 \%$. The structural challenge, in turn, leaves the country vulnerable to a volatile, rising cost driver, the oil price, as approximately a third of road transport costs is attributable to fuel (Havenga \& Simpson 2013).

The country's longest freight corridor is a key economic artery linking the industrial heartland of Gauteng to the southernmost tip, the Western Cape. The Western Cape provincial government commissioned the research presented in this article in order to deepen its understanding of the province's logistics economy and identify key actions in order to support the national policy intent of a reduction in logistics costs as a facilitator of socioeconomic reform (National Planning Commission n.d.). Davydenko and Tavasszy (2013) confirm that modelling logistics costs at the regional level permits more detailed and accurate policy decision support systems. 
In the next section, the research methodology is delineated. This is followed by the research results, which comprise: (1) positioning the Western Cape within the national economy, (2) analysing the composition of freight volumes and logistics costs in the Western Cape and (3) disaggregating the main cost driver identified in the aforementioned section, namely transport costs. Subsequently, recommendations are made to address the challenges identified through the research. Finally, concluding remarks and next steps are conveyed.

\section{Methodology}

Freight flows in South Africa are estimated in the country's Freight Demand Model (FDM), summarised into 83 commodity groups, covering 372 geographical areas, with 30-year forecasts for three growth scenarios, in tonnes and tonne-kilometres. The flow estimation is based on gravity modelling of the supply (production and imports) and demand (intermediate demand, final demand, exports and inventory investments) per geographical area per commodity group using a distance decay function as a transport resistance measure. Actual historic rail freight flows, received from the national rail transport operator (Transnet Freight Rail) per commodity per origin-destination station, are subtracted from the modelled flows, with the remainder providing a comprehensive, disaggregated estimate of road freight transport. The results of the FDM are calibrated with the National Freight Flow model (NFFM), which is a supply-side model using vehicle counts (received from Mikros Traffic Monitoring 2013) as a startingpoint. The flow model outputs are segmented to identify rail-friendly freight, the definition of which was developed in collaboration with Transnet Freight Rail, informed by desktop research. The criteria for rail-friendly freight are uniformity of freight (facilitating handling), route density (to allow for at least two trains per week), terminal density (to ensure terminal efficiency and sustainability) and distance travelled on the corridor. When these criteria are met, it ensures the optimal leveraging of rail's strengths as a long-distance bulk and heavy intermodal carrier (Havenga 2012).

The outputs from the flow models are used as the basis for calculating logistics costs. Logistics costs consist of two direct components, namely transport and warehousing, one indirect component, inventory-carrying costs, and management and administration costs. Actual rail transport costs are received from Transnet Freight Rail per commodity per origin-destination station.

For road transport cost calculations, the freight flows are summarised into typologies (the corridors, rural areas and large metropolitan centres in South Africa). The cost elements of road transport in the model are determined by a vehicle type; the vehicle type, in turn, is determined by the commodity type, typology and route of travel. The cost of holding inventory is added by calculating the average turn of each commodity in the economy, researching warehousing cost (storage and handling) and applying the prime rate to the average inventory delay. Management and administration costs are calculated by relating the relationship between the salary bill as a percentage of the costs of the transport industry for reward with the total costs of transport and warehousing to determine salary costs (Havenga et al. 2014). The remainder of this component is calculated as the average profit margin in the transport industry for reward and other outsourced logistics activities or, alternatively, as the administration charge for in-house transport or warehousing activities (Havenga et al. 2014). ${ }^{1}$ The logistics costs model was expanded to include externality costs. These are defined as costs related to freight transport that are not reflected in corporate cost structures, in effect accruing to society at large. The cost components calculated are accidents, congestion, emissions, noise, policing and land use (of roads).

The methodologies for the FDM, the NFFM and the logistics cost model have been detailed in peer reviewed publications (Havenga 2010, 2013; Havenga \& Pienaar 2012).

The calculation of provincial logistics is an extension of the same methodology employed to calculate national logistics costs. The granular geographical areas, and subsequent flow derivation, allow for flow aggregation to a provincial level.

Ring-fenced rail flows of bulk iron ore from Sishen in the Northern Cape to the Port of Saldanha on the west coast and from the inland coalfields in the east of the country to the Port of Richards Bay on the east coast are excluded from provincial-level analysis as these are not contestable road or rail flows. The rail lines basically operate as 'conveyor belts' between the mines and the respective ports, and the significant infrastructure investments are conducted as joint operations between the mines and the port owner, Transnet.

Lastly, two oil price and exchange rate scenarios were defined to illustrate the impact of exogenous volatility on logistics costs. The \$150-per-barrel scenario is based on the historical high of $\$ 147$ per barrel of Brent crude reached in mid-July 2008 (Hopkins 2008). The \$300-per-barrel scenario combines the interplay between physical production limits due to geological constraints and technological solutions (and therefore increased production) enabled by higher oil prices (Benes et al. 2012) (also see Havenga et al. 2014). It also underscores uncertainty about future oil supplies in a peakproduction world, compounded by increased demand from countries like China and India, and political turmoil in the Middle East, the world's largest oil-supply region (Franke 2012) (also see Havenga et al. 2014).

The $\mathrm{R} 12 / \$$ exchange rate scenario is informed by the high of R13.84/\$ reached in December 2001 (Grandes, Peter \& Pinaud 2003). Further depreciation to a R $15 / \$$ scenario is driven by emergency market jitters and nationalism in an environment of political turmoil and severe crude oil shortages (also see Havenga et al. 2014).

\footnotetext{
1.Road transport can be subdivided into in-house transport, which refers to the prover the the provision of road transport sevices by freight ow reward, which refers to the outsourcing of the function by freight owners to road transport companies. (The physical supply arrangements are less important than the effect of the cost of road transport on the demand; thus, the distinction should be between road transport costs factored into the market price and road transport costs borne by suppliers with allowance for proportional splits.)
} 


\section{Research results}

\section{The Western Cape relative to the national economy}

The Western Cape is the third largest provincial gross domestic product (GDP) contributor in South Africa following Gauteng and KwaZulu-Natal. In 2012, the Western Cape contributed $14 \%$ to the country's GDP, $18 \%$ of the tonnes handled in South Africa and 17\% of South Africa's logistics costs (Table 1).

On an economic subsector aggregated flow level, the manufacturing sector in the Western Cape contributes significantly more to GDP than for South Africa as a whole (the province is not endowed with significant mineral resources) (see Figure 1).

There are no substantial deviations from a percentage contribution point of view between the logistics cost components for South Africa and for the Western Cape. The large contribution for transport costs in both cases should be noted (Table 2).

TABLE 1: The Western Cape's contribution to South Africa's gross domestic product, freight volumes and logistics costs (2012).

\begin{tabular}{lccc}
\hline Dimension & South Africa & Western Cape & $\mathbf{\%}$ \\
\hline GDP (R'000 000 000) & 3139 & 439 & 14 \\
Tonnes ('000 000) & 788 & 141 & 18 \\
Logistics costs (R'000 000 000) & 405 & 70 & 17 \\
\hline
\end{tabular}

GDP, gross domestic product.

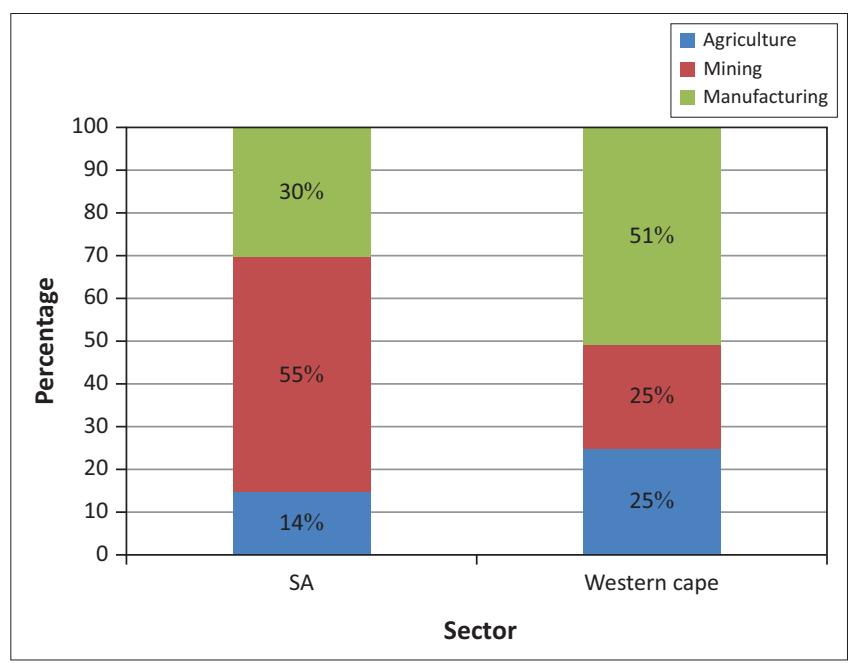

Source: Havenga, J.H., 2010, 'Logistics costs in South Africa - The case for macroeconomic measurement', South African Journal of Economics 78(4), 460-478. http://dx.doi. org/10.1111/j.1813-6982.2010.01252.x; data updated by research team

FIGURE 1: Economic sector distribution (tonnage, excluding ring-fenced iron ore and coal exports) (2012).

TABLE 2: Cost elements for South Africa and Western Cape (2012).

\begin{tabular}{|c|c|c|c|c|}
\hline Component & South Africa ( $\left.R^{\prime} 000000000\right)$ & $\begin{array}{c}\text { South Africa cost distribution } \\
(\%)\end{array}$ & Western Cape (R'000 000 000) & Western Cape cost distribution (\%) \\
\hline Transport costs & 247 & 61 & 43 & 63 \\
\hline Storage costs & 59 & 15 & 9 & 13 \\
\hline Inventory costs & 48 & 12 & 7 & 9 \\
\hline Management and administrative costs & 51 & 13 & 10 & 15 \\
\hline
\end{tabular}

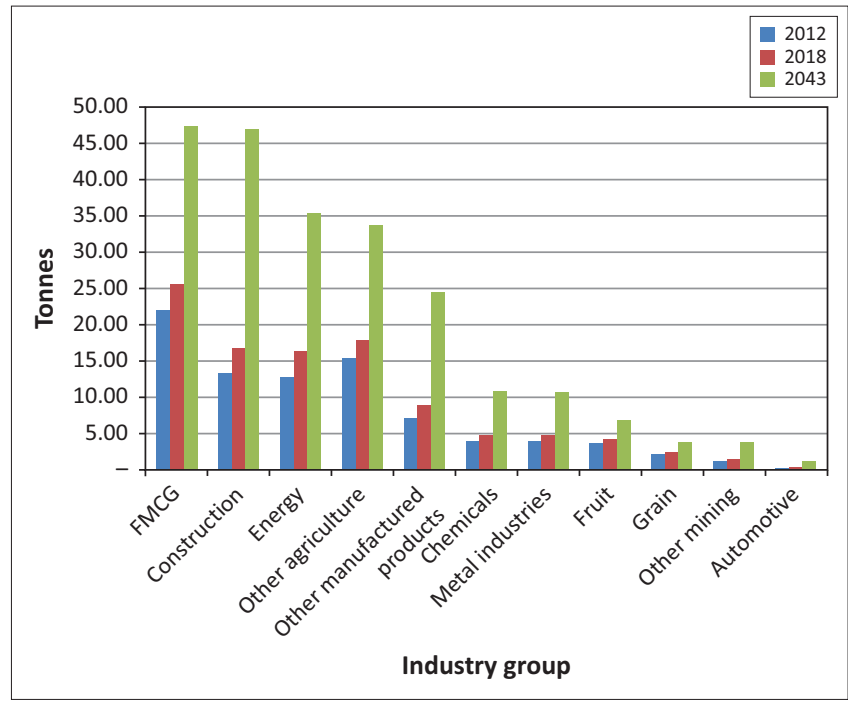

Source: Havenga, J.H., 2010, 'Logistics costs in South Africa - The case for macroeconomic measurement', South African Journal of Economics 78(4), 460-478. http://dx.doi. org/10.1111/j.1813-6982.2010.01252.x; data updated by research team

FMCG, fast-moving consumer goods.

FIGURE 2: Western Cape freight volumes (in tonnes) with forecast per industry group.

\section{Western Cape freight volume and logistics costs analysis}

The majority of freight flows in the Western Cape relate to fast-moving consumer goods (FMCG), construction, energy and agricultural activities, with FMCG and construction contributing 40\% in both 2012 and 2043 (Figure 2).

From a logistics cost point of view, a similar picture emerges. Eighty percent of logistics costs are attributable to four industry groups, namely FMCG (30\%), other agriculture (20\%), fruit (12\%) and other manufactured products $(10 \%)$ as shown in Figure $3 .^{2}$

The majority of these costs are transport costs (Figure 4). (The exception is fruit, where the requirement for refrigeration impacts the storage cost relative to the other cost elements.)

Three corridors connect the Western Cape to the rest of South Africa: the north/south N1 through the centre of the country to Gauteng, the east/west N2 to Port Elizabeth and East London and the north/south N7 on the country's west coast to Namibia. Just more than half of the 85 million total provincial tonnes (Figure 2) flow on the N1 corridor, 15\% on the $\mathrm{N} 2$ and $10 \%$ on the N7 (the remainder flowing on rural and metropolitan routes). The steady decline of rail market

2.The classification "other' is based on the grouping of commodities in the Standard Industrial Classification (SIC) coding system (Statistics South Africa 1993). In the Western Cape, other agriculture refers mostly to dry bulk commodities such as raw weodern animal feed and unprocessed tobacco, whilst other manufacturing refers to mostly non-metallic mineral products (including cement, stone and ceramics), paper and paper products. These two commodity groups require further disaggregation in follow-up work. 


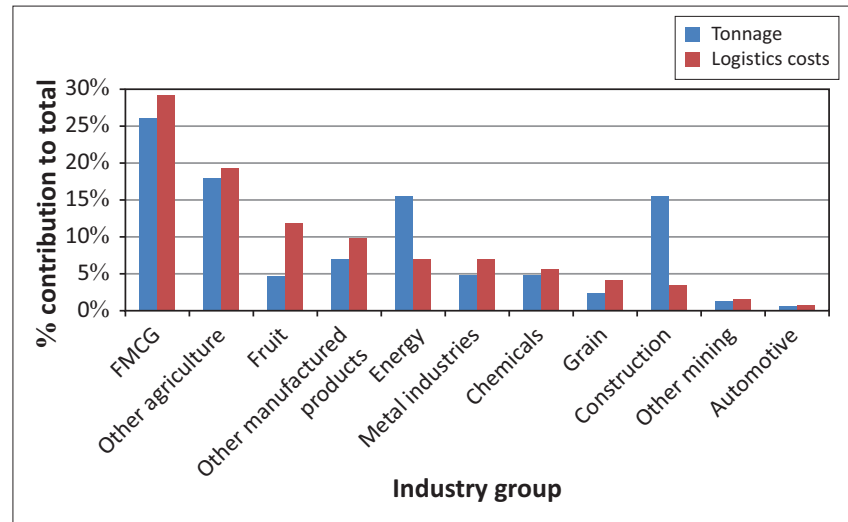

Source: Havenga, J.H., 2010, 'Logistics costs in South Africa - The case for macroeconomic measurement', South African Journal of Economics 78(4), 460-478. http://dx.doi. org/10.1111/j.1813-6982.2010.01252.x; data updated by research team

FMCG, fast-moving consumer goods.

FIGURE 3: Comparative logistics costs and tonnage contribution per industry group for Western Cape flows (2012).

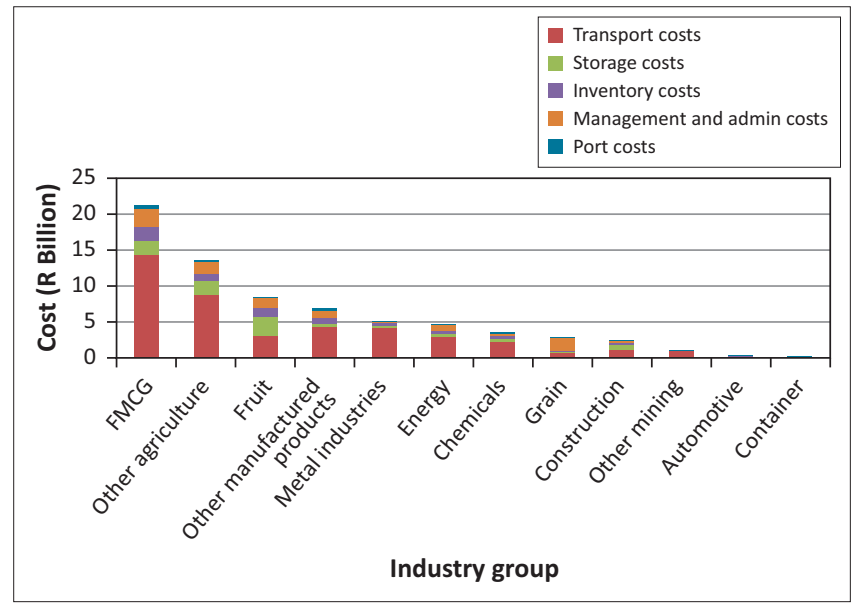

Source: Havenga, J.H., 2010, 'Logistics costs in South Africa - The case for macroeconomi measurement', South African Journal of Economics 78(4), 460-478. http://dx.doi. org/10.1111/j.1813-6982.2010.01252.x; data updated by research team

FMCG, fast-moving consumer goods.

FIGURE 4: Western Cape logistics costs elements per industry group (2012).

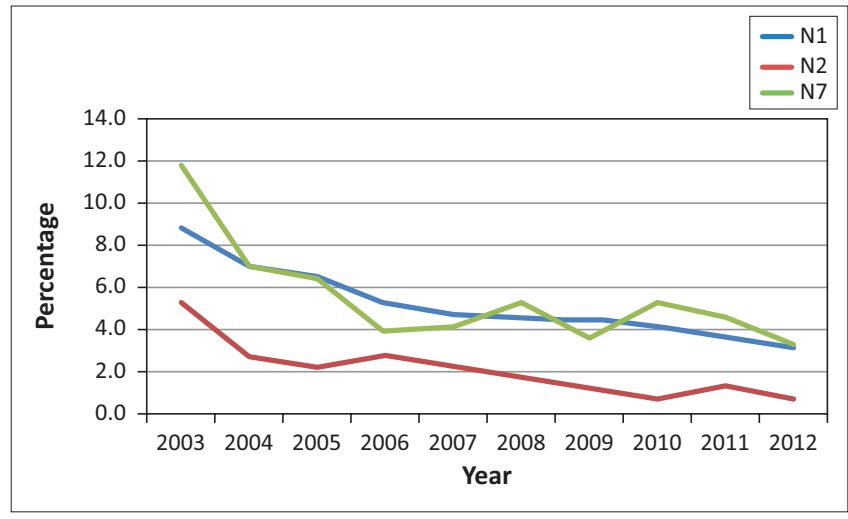

Source: Havenga, J.H., 2010, 'Logistics costs in South Africa - The case for macroeconomic measurement', South African Journal of Economics 78(4), 460-478. http://dx.doi. org/10.1111/j.1813-6982.2010.01252.x; data updated by research team

FIGURE 5: Rail market share as calculated by the National Freight Flow model.

share on all three corridors over the past decade (Figure 5) is alarming.

Approximately a third of flows on the N1 (and almost a fifth of total provincial flows) constitute FMCG, comprising

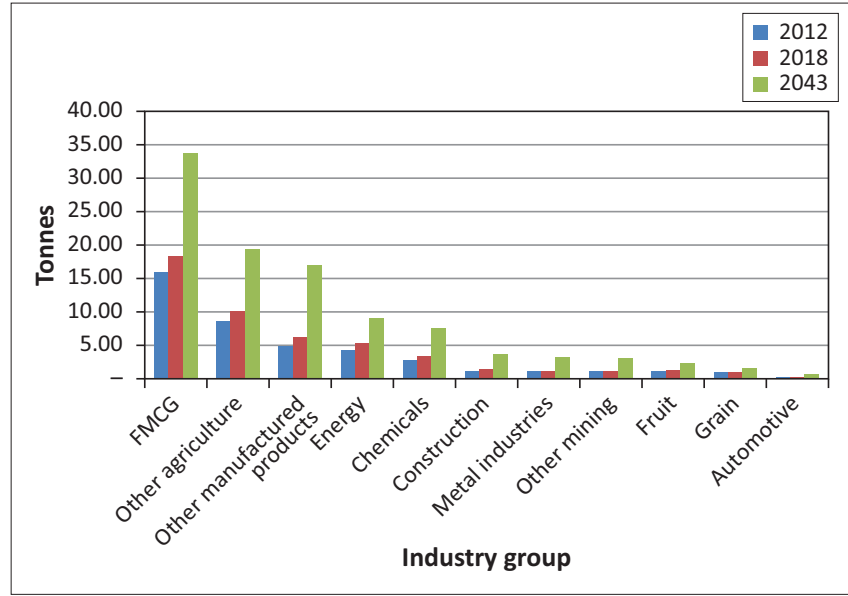

Source: Havenga, J.H., 2010, 'Logistics costs in South Africa - The case for macroeconomic measurement', South African Journal of Economics 78(4), 460-478. http://dx.doi org/10.1111/j.1813-6982.2010.01252.x; data updated by research team

FMCG, fast-moving consumer goods.

FIGURE 6: Western Cape freight volumes (in tonnes) with forecast per industry group for the N1 Cape Town to Gauteng (2012).

mostly processed foods (70\%), the remainder being beverages (Figure 6). This is followed by 'other agriculture' (18\%) and 'other manufacturing' (11\%).

The four dominant features of freight flows and logistics costs in the Western Cape - the N1, FMCG, transport costs and road transport - direct the research to a deeper analysis of long haul transport costs per industry group.

\section{Western Cape transport cost analysis}

Seventy eight percent of long distance transport costs to and from the Western Cape are attributable to road transport. When road externality costs are included, this increases road's long distance cost contribution to $82 \%$ (Table 3 ).

Fuel costs are the major driver of long haul road transport costs to and from the Western Cape, contributing 45\% in 2012, followed by maintenance (15\%), drivers (11\%) and depreciation (9\%) (Figure 7). Externalities are not currently included in freight invoicing, but if a total cost approach is followed (i.e. externality costs added to transport costs), road accidents are the combined fourth biggest overall cost driver, on par with depreciation costs, whilst road emissions are the fifth biggest. It is important to make externalities more visible as, ultimately, these costs should be internalised and reflected in the pricing structure of the different modes to ensure optimal mode selection.

The dominance of fuel cost is especially alarming given the upward trajectory in the fuel price this century (Figure 8).

The Global Analysis Trade Project, a global network of researchers and policymakers conducting quantitative analysis of international policy issues, estimates inter alia the international tariff-equivalent-impact of rising oil prices:

- At $\$ 20 /$ barrel of oil, transport costs are equivalent to a $3 \%$ tariff rate. 
TABLE 3: Transport and externality costs for long haul traffic to and from the Western Cape (2012).

\begin{tabular}{|c|c|c|c|c|}
\hline Long haul & $R^{\prime} 000000000$ & Share of transport costs $(\%)$ & Share of externality costs (\%) & $\begin{array}{l}\text { Share of total long haul costs } \\
\text { (transport + externalities) (\%) }\end{array}$ \\
\hline Road transport costs & 17.9 & 78 & - & 65 \\
\hline Rail transport costs & 5 & 22 & - & 18 \\
\hline Road externality costs & 4.7 & - & 100 & 17 \\
\hline Rail externality costs & Negligible & - & $\mathrm{n} / \mathrm{a}$ & $\mathrm{n} / \mathrm{a}$ \\
\hline Total externality costs & 4.7 & - & 100 & 100 \\
\hline
\end{tabular}

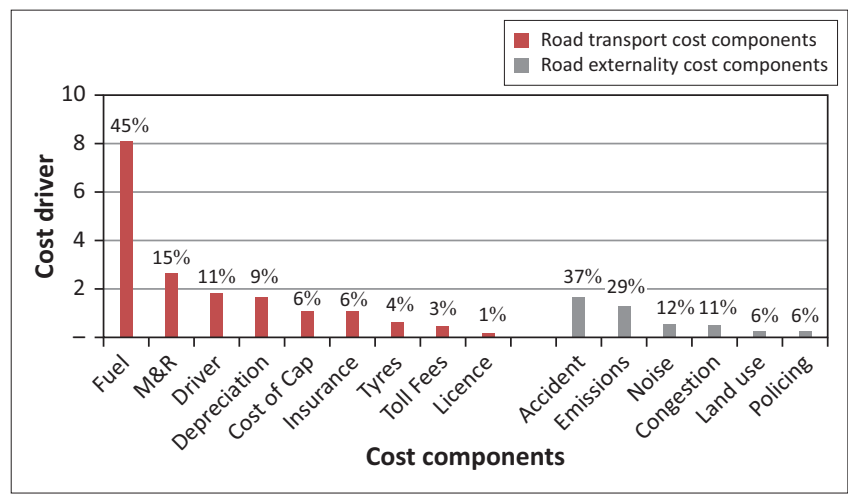

Source: Havenga, J.H., 2010, 'Logistics costs in South Africa - The case for macroeconomic measurement', South African Journal of Economics 78(4), 460-478. http://dx.doi. org/10.1111/j.1813-6982.2010.01252.x; data updated by research team

FIGURE 7: Road transport cost and road externality cost components for long haul traffic to and from the Western Cape (2012).

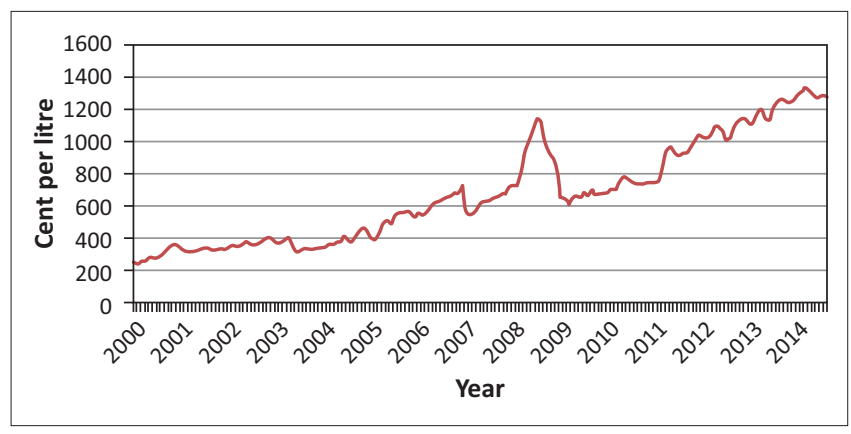

Source: Sapia, 2014, Industry overview - Old fuel prices. South African Petroleum Industry Association, viewed 22 August 2014, from http://www.sapia.co.za/industry-overview/old_ price.html

FIGURE 8: Upward trajectory of the price of diesel in South Africa.

- At $\$ 80 /$ barrel of oil, transport costs are equivalent to a tariff rate of $9 \%$.

- At $\$ 150 /$ barrel of oil, transport costs are equivalent to a tariff rate of $11 \%$ (the same as tariff rates in 1970) (Kent 2008).

This points to an interesting discrepancy in global risk management, when the collaborative global efforts relating to trade negotiation are compared to collaborative global efforts to reduce oil dependency.

Table 4 illustrates different scenarios for the effect of high international oil prices and a depreciating local currency on the Western Cape's logistics costs and transport costs as a percentage of the Western Cape GDP. Currently, the Western Cape's logistics costs are $15.9 \%$ of the GDP. This can increase to between $17 \%$ and $22 \%$ in the given scenarios. Transports costs are $9.8 \%$ of the GDP, increasing to between $12 \%$ and $17 \%$ in the given scenarios.
TABLE 4: Scenarios - exposure of Western Cape logistics costs and transport costs to the exchange rate and oil price.

\begin{tabular}{|c|c|c|c|c|}
\hline \multirow[t]{2}{*}{$\begin{array}{l}\text { Exchange } \\
\text { rate }\end{array}$} & \multicolumn{2}{|c|}{$\begin{array}{c}\text { Western Cape logistics cost } \\
\text { as a percentage of provincial } \\
\text { GDP }\end{array}$} & \multicolumn{2}{|c|}{$\begin{array}{l}\text { The Western Cape's transport } \\
\text { cost as a percentage of } \\
\text { provincial GDP }\end{array}$} \\
\hline & $\begin{array}{c}\$ 150 / \text { barrel } \\
(\%)\end{array}$ & $\begin{array}{c}\$ 300 / \\
\text { barrel (\%) }\end{array}$ & $\begin{array}{c}\$ 150 / \text { barrel } \\
(\%)\end{array}$ & $\begin{array}{c}\$ 300 / \text { barrel } \\
(\%)\end{array}$ \\
\hline $\mathrm{R} 12 / \$$ & 17 & 20 & 12 & 16 \\
\hline R15/\$ & 17 & 22 & 12 & 17 \\
\hline
\end{tabular}

GDP, gross domestic product.

The province can mitigate these volatile exogenous cost drivers, whilst meeting the freight transport needs of the province, through lowering the transport intensity of current freight flows.

\section{Recommendations}

Freight transport costs can normally be reduced by more efficient road and rail transport (including more full loads, driving vehicles longer distances per annum, better employee training, more fuel-efficient trucks and improved scheduling), but step changes can be done through modal shift only.

Dense long-distance corridors are ideal candidates for intermodal rail (Rodrigue, Slack \& Blank 2008). In Europe, rail-road intermodal solutions reduced $\mathrm{CO}_{2}$ emissions by $55 \%$ and saved $29 \%$ of energy usage compared to a road-only solution, with estimated annual environmental savings of about $€ 180$ million (European Commission 2008). According to the Association of American Railroads (2014), railroads are on average four times more fuel-efficient than trucks.

This resulted in railroads, whilst almost doubling their freight volume between 1980 and 2010, using virtually the same amount of fuel as in 1980.

The industry contribution to flows on the major provincial corridor, Cape Town to Gauteng (Figure 6), points to the highest impact short-term to medium-term intervention. FMCG (and potentially certain sub groups of other manufacturing) are ideal candidates for intermodal solutions (with long haul on rail) due to the ability of the freight to be unitised via containerisation.

North-bound, from Cape Town to Gauteng, there are currently 6.7 million tonnes of rail-friendly cargo that should shift from road transport to rail transport; south-bound, from Gauteng to Cape Town, this figure is currently 7.8 million tonnes, totalling 14.5 million tonnes (Table 5). 
TABLE 5: N1 rail-friendly freight (2012).

\begin{tabular}{lcc}
\hline Freight & $\begin{array}{c}\text { North bound (Cape Town to } \\
\text { Gauteng) }\end{array}$ & $\begin{array}{c}\text { South bound (Gauteng to Cape } \\
\text { Town) }\end{array}$ \\
\hline Total tonnes & 6.9 million & 9.4 million \\
Rail tonnes & 0.2 million & 1.6 million \\
\hline
\end{tabular}

Note: Potential shift of 14.5 million tonnes to rail.

TABLE 6: N1 freight segments - possible shift towards rail transport (2012).

\begin{tabular}{lcl}
\hline Segment & Million tonnes & Solution required \\
\hline $\begin{array}{l}\text { Domestic } \\
\text { minerals }\end{array}$ & 2 & $\begin{array}{l}\text { Low-hanging fruit - existing sidings on both } \\
\text { ends }\end{array}$ \\
$\begin{array}{l}\text { Intermediate } \\
\text { manufacturing }\end{array}$ & 1.4 & $\begin{array}{l}\text { Low-hanging fruit - existing sidings on both } \\
\text { ends }\end{array}$ \\
FMCG & 7 & $\begin{array}{l}\text { Distribution centre-to-distribution centre if } \\
\text { intermodal solutions are developed }\end{array}$ \\
Rural & 4.1 & $\begin{array}{l}\text { Rural distribution centres need to be } \\
\text { developed and roads need to be upgraded }\end{array}$ \\
\hline
\end{tabular}

FMCG, fast-moving consumer goods.

Almost half of this rail-friendly freight is FMCG (Table 6), which require intermodal solutions to shift to rail, whilst a further 3.4 million tonnes of domestic minerals and intermediate manufacturing can be more readily shifted because sidings most likely already exist on both ends of the railway line. The rural shift is more challenging given the dispersed investment requirements. Proper attention to the needs of this market segment could, however, be a game changer for South Africa's socio-economic challenges and actionable research is an imperative next step.

Guasch (2011) estimates that annual earnings per capita in rural areas with road rehabilitation projects, and thus increased access to markets, were 35\% higher than those in rural areas without road rehabilitation projects 18 months after the improved access.

Initial modelling results indicate that if intermodal solutions are not provided to shift rail-friendly, long haul freight to rail, road transport to and from the Western Cape will need to be upgraded to carry an increase of 143\% in volume in 2043.

This modal shift can be engineered in two ways. One approach is to provide an efficient service with the applicable technology at a competitive rate; the other is to facilitate a shift through various policy interventions. Given the structural challenges in the province's freight transport market, a combined approach is recommended.

In terms of providing intermodal solutions, Transnet Freight Rail entered into memoranda of understanding with Imperial Logistics and Barloworld Logistics aimed at exploring collaboration opportunities. The value of such alliances lies in combining the rail core competency in long-haul transportation with the logistics service provider's expertise in road freight logistics, distribution and end-to-end value chain management (Transnet 2013a, 2013b).

Transnet Freight Rail defines its envisaged intermodal relationships, driven by strategic partnering and joint adherence to customer requirements and service-level agreements, as follows:
- Rail offers regular, scheduled services based on guaranteed volumes and transit times between main centres and ports.

- Ports act as intermodal gateways.

- Inland terminals act as transhipment hubs.

- Road focus on distribution and door-to-door collection and delivery for value-add logistics services (Gama 2013).

The ideal is to design intermodal solutions that can behave similarly to South Africa's world-class, ring-fenced export lines. Indicatively, current costs to transport iron ore on the Sishen-Saldanha railway line are 10c per tonne-kilometre, $45 \mathrm{c}$ per tonne-kilometre to transport freight using rail transport along the Cape Town-Gauteng corridor and 60c per tonne-kilometre to transport freight via road transport along the same corridor. By increasing the utilisation of rail transport, it is probable that rail costs can be further reduced due to rail's large fixed cost component, compensating for additional handling costs.

The intensive capital investment required for intermodal solutions is often a major impediment to the development of such solutions, yet new cost-effective technologies are surfacing in the local market. RailRunner is an example of a low-cost intermodal solution developed in the USA and brought to the South African market by local engineering company, KPMC. The road vehicle is transformed to a rail vehicle in a matter of minutes as the container truck chassis is coupled to a railway bogie. Train assembly requires no lifting of the shipping container, therefore requiring far less capital equipment and cost for building and operating terminals. This allows the technology to be deployed in regions where container volumes do not support the investment in a traditional intermodal site, reducing the distance cargo has to travel by truck, whilst retaining the flexibility of trucking in the supply chain (Ash 2013; RailRunner n.d.).

Private industry concerns relating to the quantum of the modal shift, the funding model and operating inefficiencies within rail transport can only be addressed through collaborative, transparent planning processes (Rossouw 2013).

Policy interventions could relate to restrictions on gross vehicle mass, length of vehicles, axle loading, stricter safety procedures and restricting road haulage to certain times of day. The Road Transport Quality System (RTQS) was introduced in South Africa under the Road Traffic Act in the late 1980s in an effort to regulate safety, operating standards and overloading in road transport following deregulation of the transport industry. The RTQS failed inter alia due to onerous certification requirements and challenges with the privatisation of testing stations. Due to overloading, road conditions worsened to the detriment of both freight owners and operators and significant losses were incurred due to inter alia accidents and vehicle inefficiencies (Collings 2009; Furter 2014). The Road Transport Management System (RTMS) was initiated in 2003 in an attempt to self-regulate 
South Africa's road freight transport sector by improving overall efficiency and reducing transport costs. RTMS certified organisations report significant successes in the reduction and minimisation of overloading, prevention of road damage and preservation of road infrastructure, safety and compliance, driver wellness and training and development. For example, RTMS certified organisations reported a reduction in the number crashes of between $40 \%$ and $66 \%$ over the past five years, translating into a decrease in the cost of crashes from $5 \%$ of revenue to $1.3 \%$ of revenue over a five-year period for one road haulier. Overloading in the forestry sector was reduced from $18 \%$ to $6 \%$ in the decade leading up to December 2010, whilst the sugar industry reduced overloading from more than $30 \%$ prior to 2007 to approximately 7\% in 2011. The City of Cape Town Electricity Support Services improved fuel consumption from $5.9 \mathrm{~km} / \mathrm{L}$ in $2007 / 08$ to $8.3 \mathrm{~km} / \mathrm{L}$ in $2010 / 2011$. These results are indicative of what can be achieved; substantial efforts are, however, required to raise awareness to increase certification and compliance (Nordengen \& Naidoo 2014). The policy interventions envisaged must be designed to internalise and so reduce the costs of the externalities, as any attempt at the imposition of regulation on the supply - that is, reverting back to the Road Transport Act - would be not only a retrograde step, but an economic disaster.

\section{Conclusion}

Analysis of freight flows and logistics costs in the Western Cape province of South Africa reveals four dominant characteristics that lead to a distinct recommendation to reduce provincial logistics costs and externalities. These characteristics are that (1) $50 \%$ of total provincial freight flows on the N1 corridor to Gauteng, (2) a third of these flows constitute FMCG, (3) a third of provincial freight logistics costs are attributable to FMCG and (4) transport contributes two-thirds to FMCG logistics costs. Dense, long distance corridors are ideal candidates for intermodal solutions and FMCG are the most common goods benefiting from such solutions. Memoranda of understanding have already been signed between Transnet Freight Rail and two global logistics players to explore such solutions and collaboration with industry is ongoing to facilitate a modal shift. A sense of urgency in execution is however required as the exogenous risk caused by South Africa's excessive dependence on long distance road freight transport is becoming untenable in a global economy where fossil fuel supply is at risk due to natural and political constraints.

The following areas require more in-depth research:

- Most importantly, furthering the existing initiatives to develop domestic intermodal solutions.

- Models for the sustainable provision of freight transport and end-market access to rural communities within the Western Cape.

- Further disaggregation of the SIC groupings such as other agriculture and other manufacturing to facilitate more informed decision-making, given their contribution to freight flows and logistics costs in the province.
The expansion of this research should include and further existing work needs to be done on:

- Addressing the current and future capacity constraints at the Port of Cape Town and seamlessly integrating intermodal solutions with this critical provincial facility.

- Investigating options for addressing the freight logistics challenges through re-localisation of demand and increased beneficiation within the province, which could reduce the demand for logistics services relative to output, thereby reducing logistics costs and externalities.

\section{Acknowledgements Competing interests}

The authors declare that they have no financial or personal relationships that may have inappropriately influenced them in writing this article.

\section{Authors' contributions}

J.H.H. (Stellenbosch University) was the project leader, conducted the research and co-authored the article. L.L.G.-G. (Stellenbosch University) co-authored the report on the original research and the article. A.d.B. (Stellenbosch University) was the project manager for the research. Z.S. (Stellenbosch University) co-authored the report on the original research.

\section{References}

Ash, P., 2013, 'New plan to move freight on rail could slash road deaths', Business Day Live, viewed 27 August 2014, from http://www.bdlive.co.za/business/ transport/2013/12/01/new-plan-to-move-freight-on-rail-could-slash-road-deaths

Association of American Railroads, 2014, Rail intermodal keeps America moving, viewed 01 September 2014, from https://www.aar.org/keyissues/Documents/ Background-Papers/Rail\%20Intermodal.pdf

Benes, J., Chauvet, M., Kamenik, O., Kumhof, M., Laxton, D., Mursula, S., et al., 2012, The future of oil: Geology versus technology, working paper [WP/12/109], IMF, Washington.

Collings, P., 2009, Optimisation is a reality - RTMS at work in sugar and coal transport viewed 01 September 2014, from http://www.fleetwatch.co.za/magazines/ Oct2009/28-Optimisation\%20is\%20a\%20reality.htm

Davydenko, I.Y. \& Tavasszy, L.A., 2013, 'Estimation of warehouse throughput in freight transport demand model for the Netherlands', Transportation Research Record: Journal of the Transportation Research Board 2379 (Freight Operations 2013) 9-17. http://dx.doi.org/10.3141/2379-02

European Commission, 2008, ICT and e-business impact in the transport and logistics services industry. Study report No. 05/2008, Brussels, e-Business Watch.

Franke, P., 2012, Crude oil is going to $\$ 500$ a barrel (Part 2), viewed 01 September 2014, from http://beta.fool.com/quantemonics/2012/03/21/crude-oil-going500-barrel-part-2/3024/

Furter, E., 2014, Road transport management system (RTMS) certification and concessions, viewed 01 September 2014, from http://sheqafrica.com/roadtransport-management-system/

Gama, S., 2013, Plans for the development of South Africa's supply chains, viewed 27 August 2014, from http://saaff.org.za/congress2013/80ctober_Transnet Siyabonga\%20Gama.pdf

Grandes, M., Peter, M. \& Pinaud, N., 2003, The currency premium and local-currency denominated debt costs in South Africa, viewed 01 September 2014, from http:// www.oecd.org/dataoecd/52/44/23375078.pdf

Guasch, J.L., 2011, 'Logistics as a driver for competitiveness in Latin America and the Caribbean', presentation at the Fifth Americas Competiveness Forum for the Inter-American Development Bank and Compete Caribbean, Santo Domingo, Dominican Republic, 5-7 October.

Havenga, J.H., 2010, 'Logistics costs in South Africa - The case for macroeconomic measurement', South African Journal of Economics 78(4), 460-478. http://dx.doi. org/10.1111/j.1813-6982.2010.01252.x

Havenga, J.H., 2012, 'Rail renaissance based on strategic market segmentation principles', Southern African Business Review 16(1), 1-21.

Havenga, J.H., 2013, 'The importance of disaggregated freight flow forecasts to inform transport infrastructure investments', Journal of Transport and Supply Chain Management 7(1), 1-7. http://dx.doi.org/10.4102/jtscm.v7i1.106 
Havenga, J.H. \& Pienaar, W.J., 2012, 'The creation and application of a national freight flow model for South Africa', Journal of the South African Institution of Civil Engineering 54(1), 2-13.

Havenga, J.H. \& Simpson, Z., 2013, 10th Annual state of logistics survey for South Africa: Bold steps forward, viewed 28 August 2014, from http://www.csir.co.za/sol/

Havenga, J.H., Simpson, Z.P., De Bod, A. \& Viljoen, N.M., 2014, 'South Africa's rising logistics costs: An uncertain future', Journal of Transport and Supply Chain Management 8(1), Art. \#155, 7 pages. http://dx.doi.org/10.4102/jtscm.v8i1.155

Hopkins, K., 2008, 'Fuel prices: Iran missile launches send oil to $\$ 147$ a barrel record', The Guardian, 12 July. Available from http://www.guardian.co.uk/business/2008/ jul/12/oil.commodities

Kent, P.E., 2008, Trade-related transport and logistics, viewed 31 August 2014, from http://egateg.usaid.gov/sites/default/files/Trade-Related\%20Transport $\% 20$ and\%20Logistics.pdf

Mikros Traffic Monitoring, 2013, SANRAL traffic counting yearbook, South African National Roads Agency Limited, Pretoria.

National Planning Commission, n.d., Our future - Make it work. National Developmen Plan 2030, viewed 01 September 2014, from http://www.npconline.co.za/ MediaLib/Downloads/Downloads/NDP\%202030\%20-\%200ur\%20future $\% 20$ $-\% 20$ make $\% 20$ it $\% 20$ work.pdf

Nordengen, P.A. \& Naidoo, O.J., 2014, 'Evaluation of the Road Transport Management System, a self-regulation initiative in heavy vehicle transport in South Africa' paper presented at the Transport Research Arena, Paris, 14-17 April.

North, P., 2010, 'Eco-localisation as a progressive response to peak oil and climate change - A sympathetic critique', Geoforum 41(4), 585-594. http://dx.doi. org/10.1016/j.geoforum.2009.04.013

RailRunner, n.d., Innovating intermodal, viewed 27 August 2014, from http://www. railrunner.com
Rantasila, K., 2010, 'Measuring national logistics costs', Master's thesis, Turku School of Economics, University of Turku, Turku.

Roberts, P.O., 2003, 'Supply chain management: New directions for developing economies', PSD Professionals' Forum, viewed 4 June 2014, from http://www. logmgt.nkmu.edu.tw/news/articles/SCM-New\%20Direction.pdf

Rodrigue, J-P., Comtois, C. \& Slack, B., 2009, The geography of transport systems, 2nd edn., Routledge, New York.

Rodrigue, J-P., Slack, B. \& Blank, S., 2008, Transport corridors in North America, viewed 01 September 2014, from http://people.hofstra.edu/geotrans/eng/ch2en/ appl2en/ch2a1en.html

Rossouw, C., 2013, Challenges facing South Africa's 'road-to-rail' imperative - A private industry perspective. 10th Annual State of Logistics Survey for South Africa: Bold steps forward, viewed 28 August 2014, from http://www.csir.co.za/sol/

Sapia, 2014, Industry overview - Old fuel prices. South African Petroleum Industry Association, viewed 22 August 2014, from http://www.sapia.co.za/industryoverview/old_price.html

Statistics South Africa, 1993, Standard industrial classification of all economic activities (SIC) - Fifth edition, viewed 31 August 2014, from http://www.statssa. gov.za/additional_services/sic/sic.htm.

Transnet, 2013a, 'Transnet Freight Rail and Imperial Logistics partner to collaborate in road to rail migration', media release, 04 October.

Transnet, 2013b, 'Transnet Freight Rail and Barloworld Logistics partner to collaborate in road to rail migration', media release, 22 October.

Tsedu, T., 2012, Joint media statement by the CSIR, Imperial Logistics and Stellenbosch University. South African logistics must gear up for change to become global partner: Release of 8th State of Logistics survey, viewed 28 August 2014, from partner: Release of 8th State of Logistics survey, viewed 28 August 2014, from
http://ntww1.csir.co.za/plsql/ptl0002/PTL0002_PGE157_MEDIA_REL?MEDIA_ RELEASE_NO=7525112 